\title{
MODEL OF CLIMATE AND LAND-USE CHANGES IMPACT ON WATER SECURITY IN AMBON CITY, INDONESIA
}

\author{
R. A. Barkey ${ }^{a}$, M. F. Mappiasse ${ }^{a}$, M. Nursaputra ${ }^{a}$ \\ ${ }^{a}$ Research Center for Natural Heritage, Biodiversity and Climate Change, Hasanuddin University, Indonesia
}

\section{Article Info:}

Received: 20 November 2016

in revised form: 13 January 2017

Accepted: 28 March 2017

Available Online: 1 April 2017

\section{Keywords:}

Climate Change, Land use Change,

Water Security, Land use Planning

\section{Corresponding Author:}

Roland A. Barkey

Research Center for Natural Heritage, Biodiversity and Climate

Change, Hasanuddin University, Indonesia

Email: rolandbarkey@gmail.com

\begin{abstract}
Ambon City is the center of national activities in Maluku province, established under Presidential Decree 77 issued in 2014 about spatial planning of Maluku Islands. Ambon is a strategic region in terms of development in agriculture and fisheries sectors. Development of the region caused this area to be extremely vulnerable to the issues on water security. Seven watersheds which are Air Manis, Hutumury, Passo, Tulehu, Wae Batu Merah, Wae Lela and Wae Sikula affect the water system in Ambon City. Therefore, this study was conducted to determine the impact of climate and land use change on water availability in seven watersheds in Ambon City. The analysis was performed using a Soil and Water Assessment Tool (SWAT) Model in order to analyze climate changes on the period of 1987-1996 (past), of 2004-2013 (present) and climate projection on the period 2035s (future) and equally to analyze land use data in 1996 and 2014. The results of the research indicated that land use in the study area has changed since 1996 to 2014. Forest area decreased around 32.45\%, while residential areas and agriculture land increased $56.01 \%$ and $19.80 \%$, respectively. The results of SWAT model presented the water availability amount to 1,127,011,350 $\mathrm{m}^{3} /$ year on the period of 1987-1996. During the period of 2004-2013, it has been reduced to $1,076,548,720 \mathrm{~m}^{3} /$ year (around $4.48 \%$ decrease). The results of the prediction of future water availability in the period of $2035 \mathrm{~s}$ estimated a decrease of water availability around $4.69 \%\left(1,026,086,090 \mathrm{~m}^{3} /\right.$ year). Land use and climate change have greatly contributed to the water availability in seven watersheds of Ambon City. Ambon City is in need of land use planning especially the application of spatial plan. The maintenance of forest area is indispensable. In built-up areas, it is essential to implement green space and water harvesting in order to secure water availability in the future.
\end{abstract}

How to cite (APA 6th Style):

Barkey, R. A., Mappiasse, M. F., \& Nursaputra, M. (2017). Model of climate and land-use changes impact on water security in Ambon City, Indonesia. Geoplanning: Journal of Geomatics and Planning, 4(1), 97-108. doi:10.14710/geoplanning.4.1.97-108

\section{INTRODUCTION}

At present, water resources become an important issue in many regions in Indonesia. This has procreated the encouragement of efficient and effective water use. The objective is that the water resources existing today can meet various needs in order to improve the welfare and prosperity of all human beings in all aspects of life. In general, two causes of water insecurity such as the low capacity of water resources management and the disruption of water resource itself are present. The high use of the land on catchment areas, particularly in upstream region triggers disruptions in water resources. A change on natural factors such as climate related to water resources was the impact of high human activity in the use of land such as in the case of land built up correspondingly generate. Deforestation has equally led to a transformation of area from having cold to warm temperatures. The CSIRO (2012) has reported that scientific evidence of climate change was real. The study of CSIRO Australia showed average temperature rise of $0.29-0.39^{\circ} \mathrm{C}$ in the six developed climate models. Since the climate change could change water availability which will forwardly affect all aspects of human life, its diversity should be considered in regional planning. 
Based on data from the Ministry of Research, Technology and Higher Education, about 70\% of drinking water sources in Indonesia have decreased in quality and quantity. The water crisis causes disruption of the water availability for the community. People with difficult water access are obliged to reach distant water source and yet with poor quality of water. In Indonesia, the drinking water supply is a consistent and complex problem. (Lokollo, 2000) suggested that the decrease of minimum discharge increases of maximum discharge, rainfall can be considered as random factor. Meanwhile, the increase of runoff coefficient is a limiting factor that leads to the decline in the water availability in a region due to the spatial planning for unsustainable water resources. Spatial planning for water resources conducted with the aim of managing the land area by providing the proper place for the water in order to fulfill the maximum into the soil through infiltration, thereby reducing the high surface runoff. Land use change is an important driver to change the hydrological response of a watershed (Niraula, Meixner, \& Norman, 2015; Sarwuan, Beka, \& Ogbole, 2016).

Study of changes in land use has been frequently used in assessing the hydrological response in some watersheds in the larger islands in the world, especially in the basin with rapid human development. Land use is the study of the specific unit in a watershed due to its impact to the increase in population and economic growth of a region and due to its role as a component of the watershed that can be managed. The results of the study by Nie et al. (2011), obtained information that transformation of land use into residential areas in the period 1973, 1986, 1992 and 1997 in San Pedro watershed, Arizona has decreased groundwater flow and increased evapotranspiration, thereby decreased of water yield in the region. The use of land for agriculture correspondingly resulted in the increase of runoff from the period 1956 to 2010 in the Heihe watershed, China Nian et al. (2014). The decrease of forest area by $16.3 \%$ in the catchment area of the Be river, Vietnam could increase discharge flow by $0.2-0.4 \%$, sediment by $1.8-3.0 \%$ and runoff by $4.8-10.7 \%$ (Khoi \& Suetsugi, 2014). Conversion of land in the catchment area has led to increased runoff index of each watershed, as well as the rapidly increasing flow concentration time. Change of water system in the watershed, causing a phenomenon with negative impact for community such as intensity of floods and droughts has exacerbated (Chen \& Yu, 2015; Memarian, Tajbakhsh, \& Balasundram, 2013; Pervez \& Henebry, 2015; Schilling et al., 2014; Zhang et al., 2016), as is the case today in the Ambon City (Putuhena, 2013).

Compared to islands in Indonesia, Ambon City as a center of growth in Maluku province has a characteristic of Small Island with mountainous contours leading to the formation of many streams in this region. Thus, it causes rapid fluctuations in the flow from upstream to downstream in the region due to its narrow, short and steep width stream. Characteristics of river flow in this region are extremely different from the characteristics of the river flow in watersheds in other places, especially on a large island with a large watershed. The habitant in these areas consumes water from the springs and the river. This characteristic of the Ambon City has also generated a lack of flat areas for the development of an ideal settlement area. In fact, the increase of population growth in the city of Ambon requires land to reside. Thus, the areas of settlements were then reached the mountainous contours, part of upstream on catchment areas for rivers located in the Ambon City. These conditions resulted in the destruction of water catchment areas, especially in the upstream region. Thus, spatial planning for water resources in watersheds in the Ambon City is indispensable.

The role of forests in the upper stream of the watershed is accordingly vital considering forested land can increase water infiltration into the soil. The results of the study by Jacob (2009) on sub watershed Batu Gantung (Wae Batu Merah Watershed) stated that the decrease in forest area in the region has raised the surface flow, so that it needs at least $30 \%$ of the forest area in the sub watershed Batu Gantung to reduce the surface flow. To solve the problem of water security in the city of Ambon, sustainable resource management is required. Planning and management should be based on the carrying capacity of ecosystems and land on water security in the future. The concept of carrying capacity should be used as the framework for the operation of natural resource and sustainable environmental management. Therefore, this study was conducted in order to determine the level of water security affecting the Ambon City due to changes in land use and climate impacts on watersheds. 


\section{DATA AND METHODS}

\subsection{Study Area}

The study was conducted in the Ambon City in the objective to analyze the level of water resistance face to changes in land use and climate. Ambon city, the center of national activities in Maluku province, Indonesia was established under Presidential Decree 77 of 2014 on spatial planning Maluku Islands as a region in terms of development of agriculture and fisheries sectors. Ambon city has an area of $359.45 \mathrm{~km}^{2}$, with five districts administrative namely Nusaniwe, Sirimau, Baguala, Teluk Ambon and South Leitimur. The land area in Ambon City is affected by seven watersheds that regulate the water system in the region namely Air Manis, Hutumury, Passo, Tulehu, Wae Batu Merah, Wae Lela and Wae Sikula. Spatial distribution of watersheds that affect the city of Ambon is presented in Figure 1.

Figure 1. Map of watershed in Ambon City

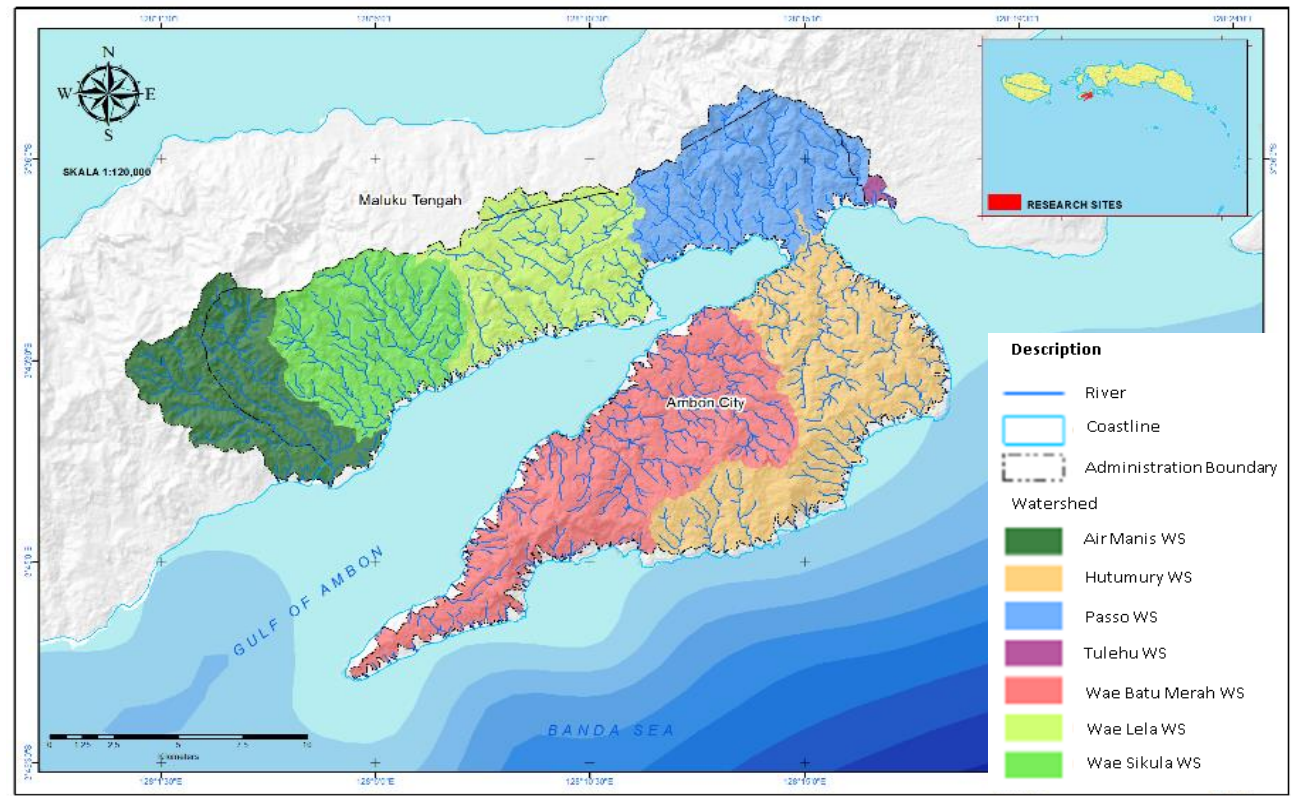

The area of Ambon City is mostly hilly and steep slopes above 20 degree with an area of about $73 \%$ and plain areas with a slope of less than 20 degree with an area of about $17 \%$. The influence of geographical conditions where the composition of the steep slopes area more dominant, have led to insufficient space for settlement development. However, with the increase of population growth in the city of Ambon, the need for the region for land settlements has equally increased especially in unsuitable locations. This has led to the opening of steep forested land into land settlements affecting the region of upstream watersheds. Logically, this has also resulted to an imbalance of the water system on seven watersheds affecting Ambon City as shown by water shortages in the dry season and floods in the rainy season happening every year. The problems of the water system on the watersheds in Ambon City are most closely related to the fulfillment of the water availability in the present and the future.

\subsection{Data Acquisitions for the SWAT Model}

To simulate, this study used a simple model in order to describe the condition of hydrological watersheds that affect water security in Ambon City. The SWAT (Soil and Water Assessment Tool) model was used to generate information on the availability of water every watershed. SWAT model is designed to predict the impact of land use and management practices of land to water, sediment, and agricultural chemicals that enter the river or body of water in a watershed having the characteristics of soil types, land use and management of complex in the long term. SWAT could directly model the processes of physics and chemistry using Hydrologic Response Unit (HRU) analysis in each analyzed sub-watershed (Arnold et al., 2013). For the operationalization of hydrological models using a SWAT model, ArcSWAT software was utilized. It was then connected with the application of ESRI (ArCGIS) as an additional extension are based 
GUI (Graphical User Interface) (Olivera et al., 2006). In the simulation of SWAT models, some data were analyzed and classified into spatial and text data. The data was prepared in the SWAT model simulation, including:

a. Digital elevation model (DEM), which has been made with GIS approach through Topo to Raster Interpolation method using boundary data of the study area (watersheds boundary in Ambon City), contours data at intervals of 5 meters were extracted from the ASTER DEM with 30-meter resolution (http://gdex.cr.usgs.gov/gdex/), the river network data and point elevation data from Topography maps of Indonesia (http://portal.ina-sdi.or.id/).

b. Land cover data on 1996 and 2014 were obtained from the time series of land cover data Ministry of Environment and Forestry and interpretation results Landsat 8 scale of 1: 50.000, then the data were exported into a data with raster format for the SWAT model simulation.

c. Soil type data from RePPProt Map (Regional Physical Planning Project for Transmigration), which was equipped with physical and chemical parameters of the land acquired from land information database from RePPProt Map and Web Soil USDA Natural Resource Conservation Service. Data type of soil was then exported into a data with raster format.

d. The daily global climate data were obtained from the Global Weather (http://globalweather.tamu.edu/) in the period 1987-1996 (past) and the period 2004-2013 (actual), includes data rainfall (mm), temperature $\left({ }^{\circ} \mathrm{C}\right)$, humidity (fraction), solar radiation $(\mathrm{MJ} / \mathrm{m} 2)$ and wind speed $(\mathrm{m} / \mathrm{s})$.

\subsection{SWAT Model Processing}

The use of SWAT models to analysis the water security in the watershed was instrumental in generating information on the conditions of the water system. This information could be used as reference and guidance for stakeholders in the development management giving an overview of a region presently and utterly managed. The SWAT model resulted in hydrological response unit or HRU overlaying land use maps, soil maps and detailed with physical and chemical information, and class slopes map.

Firstly, the SWAT model simulation watersheds in Ambon City began with the formation of the hydrological boundaries, which were analyzed using DEM data to extract the networking data of watersheds, sub-watersheds and river. Secondly, the HRU (Hydrology Response Unit) was formed by overlaying land use data (land use in 1996 and 2014), soil type data and slope class data extracted from DEM data. Thirdly, a re-write database after climate data at the input was carried out. Fourthly, the SWAT model was run with time adjusting in accordance to the analysis of selected climatic period. The period of analysis used in this study was the period from 1987 to 1996 (past) and the period from 2004 to 2013 (present). The results of this analysis generated information on the water availability in each watershed. Water availability information for each watershed in the Ambon City was furtherly compared with the level of the water demand of the community to illustrate the level of water security in this region due to changes in land use and climate factor. Analysis of water demand in the Ambon City was calculated based on the SNI.6728.1 2015 on the preparation of spatial balance water resources (BSN, 2015).

Figure. 2 Mechanism of SWAT Model

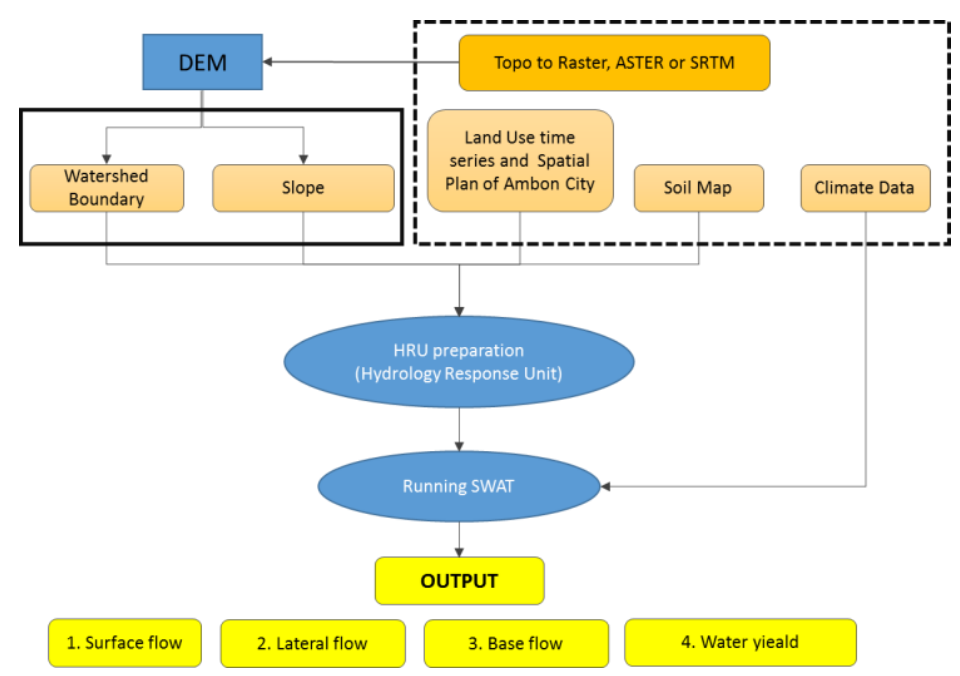


SWAT model output on each watershed affecting Ambon City produced water availability data for the period of 1987-1996 (past) and the period of 2004-2013 (present). The outputs of the change rate were analyzed to obtain data water availability on period 2035s (future). Analysis of the water availability is a stage to define the output generated from the simulation SWAT model. In the SWAT model, water availability is termed as the water yield obtained in a watershed (Arnold et al., 2013). Water yield was obtained from the following formula:

$$
W Y L D=S U R Q+L A T Q+G W Q-\text { TLOSS }- \text { pond abstractions }
$$

\section{Explanation:}

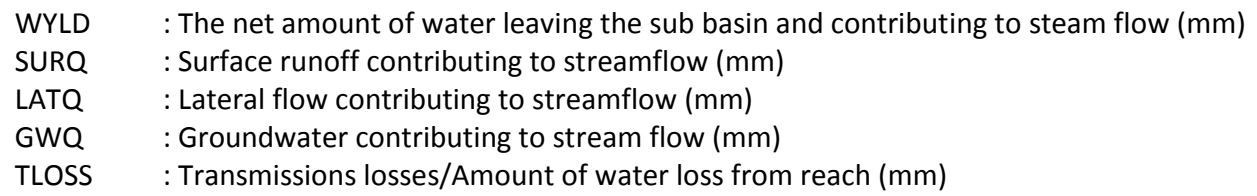

After the output of water availability was defined, the value range of water availability level in each watershed was generated in order to determine the level of water availability in the region. With the ability to produce hydrological sub-watershed information in the watershed, SWAT data could be a reference in the control of natural resources and environmental management of watersheds. Sub-watershed with a problem can be identified and evaluated so that environmental improvement efforts-based watersheds could be undertaken. Simulation of watershed improvement can be done by arranging multiple land use management plans or action plans for implementation by involved stakeholders in the watershed. The management plan was then simulated using SWAT models to obtain the best management plan.

\section{RESULTS AND DISCUSSION}

\subsection{Land Use and Climate Change Analysis}

The results of this study showed that the rate of land conversion from 1996 until 2014 was high. There were a type of land use that has the addition and reduction in area. Land use that has the reduction area was secondary dry forest and open land. While, land use that has the addition area was pasture, settlements, dry land agricultural and mix dry land farming with shrubs and bushes. Conditions of Land Use change in Ambon City was dominated by forest land (14.3\%) into settlement area (6.2\%), agricultural lands (5.1\%) and other land (pasture; shrubs and bushes) (3\%). The details of the changes in land use are presented in Table 1 and Figure 2.

Table 1. Land use condition in Ambon City

\begin{tabular}{|c|rrrrrr|} 
No Land Use & \multicolumn{2}{c}{ on $\mathbf{1 9 9 6}$} & \multicolumn{2}{c}{ on 2014 } & \multicolumn{1}{c}{ Rate of } \\
& & Area $(\mathrm{Ha})$ & Percentage & Area (Ha) & Percentage & Changes (ha) \\
\hline $\mathbf{1}$ & Airport & 92.8 & 0.3 & 92.8 & 0.3 & 0.0 \\
\hline $\mathbf{2}$ & Primary Dryland Forest & 438.0 & 1.4 & 438.0 & 1.4 & 0.0 \\
\hline $\mathbf{3}$ & Secondary Dryland Forest & $13,473.2$ & 44.0 & $9,099.8$ & 29.7 & $-4,373.4$ \\
\hline $\mathbf{4}$ & Secondary Mangrove Forest & 30.3 & 0.1 & 30.3 & 0.1 & 0.0 \\
\hline $\mathbf{5}$ & Pasture & - & - & 213.4 & 0.7 & +213.4 \\
\hline $\mathbf{6}$ & Settlement & $1,501.3$ & 4.9 & $3,413.5$ & 11.1 & $+1,912.2$ \\
\hline $\mathbf{7}$ & Dryland Agriculture & 484.8 & 1.6 & 842.9 & 2.8 & +358.1 \\
\hline $\mathbf{8}$ & Mix Dryland Agriculture & $7,365.9$ & 24.0 & $8,562.3$ & 27.9 & $+1,196.5$ \\
\hline $\mathbf{9}$ & Scrub and Busses & $7,185.0$ & 23.5 & $7,924.7$ & 25.9 & +739.7 \\
\hline $\mathbf{1 0}$ & Bare Land & 68.1 & 0.2 & 21.5 & 0.1 & -46.6 \\
\hline & $\quad$ Total & $30,639.0$ & 100.0 & $30,639.0$ & 100.0 & \\
\hline
\end{tabular}


The table illustrates that the process of change was caused by human factors where most of the land cover converted into settlements and dry land agriculture. This is due to the increasing population from year to year superior to the birth rate or population resettled from other areas. Consequently, the land conversion for farming is inevitable in which it has been the biggest income of population in Ambon City. Land use change from vegetated land into built-up area almost occurred in all watersheds in the world, not just in the large watershed but in small watersheds such as in Ambon correspondingly with the increased human activities in the region. The results of the research by Butt et al. (2015) in Simly watershed, Pakistan with an area of about 5,000 ha (small watershed classification) has shown that from the period analysis of 1992-2012 there has been a decline in forest and agricultural land into residential land for $38.2 \%$ and $74.3 \%$, respectively. Monitoring of land use on Oben Area, Niger River, Nigeria equally gave an overview of high change of land use in some watersheds in the world with the transfer function of the protected forest area into built-up area for industry in a period of 28 years (1987-2015) (Sarwuan et al., 2016). Most of the problems of changes in land use in watersheds in the world were caused by the activity of the community, therefore proper land use planning for the development of effective strategies in sustainable watershed is required (Iqbal et al., 2012).

Figure 2. (a) Map of land use in 1996; (b) map of land use in 2014
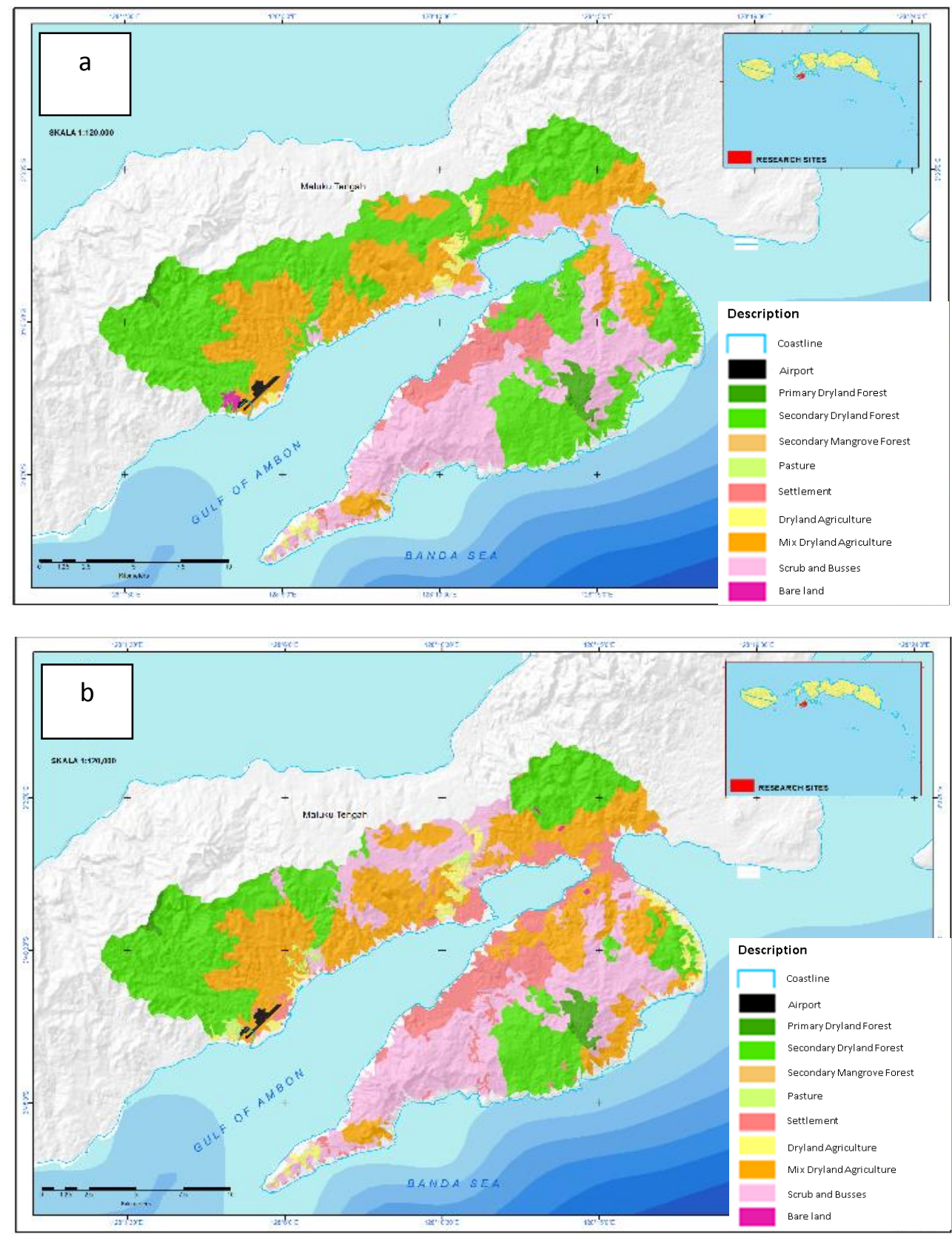
The impact of the land use change in Ambon City caused changes in natural factors such as climate. Community activities that convert forests into non-forested land has transformed climate change in this region generating as a random rain and increased temperatures. Climate in Ambon City is a tropical sea and season, because the location of Ambon island surrounded by the sea. Therefore, the Ambon climate is strongly influenced by the ocean and coincides with the climatic seasons namely west season (north) and east season (southeast). Change of seasons always is punctuated by a transition season. West season generally runs from December to March, while in April a transition period to East season lasts from May to October, followed by a transition period in November to the West season. Based on analysis of climate data from Global Weather for Ambon City area, a trend of change was shown in Figure 3.

Figure 3. Rainfall condition on period 1987-1996 (past) and Period 2004-2013 (actual) in Ambon City

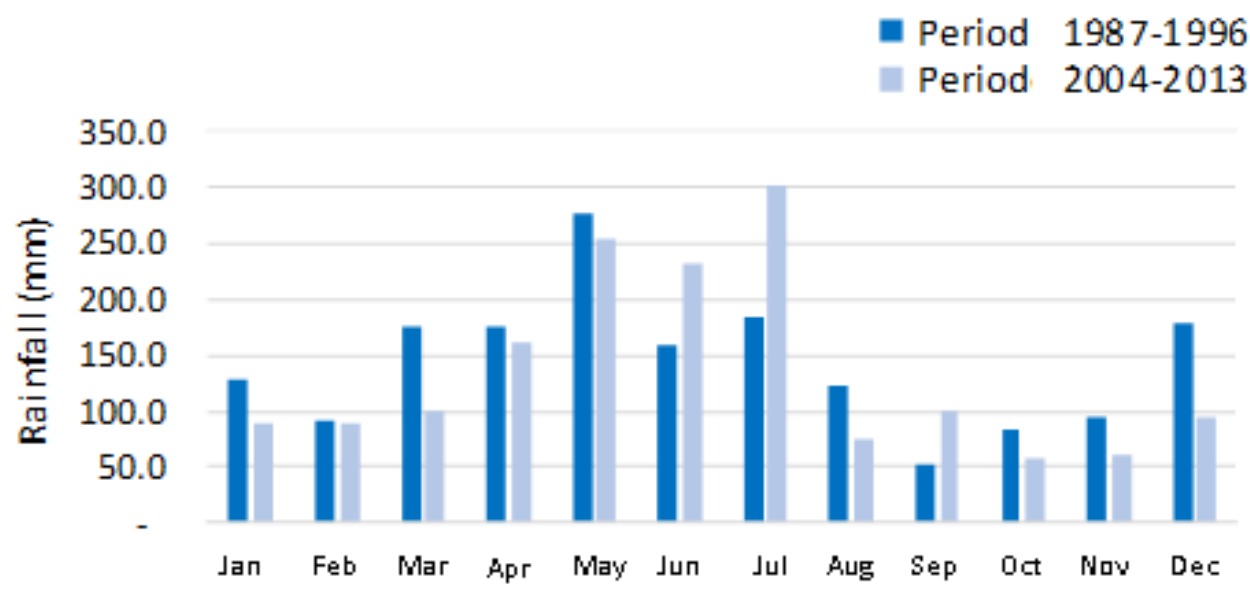

Comparison of precipitation obtained from climate data Global Weather indicated a decline in the actual period of rainfall in west season between December and March. While in April and early May which is transition to the east season, a decline in rainfall was detected. But, the east season in June and July predicted the increase of rainfall. In connection with this research, the future challenges related to climate change in Ambon City is expected to have a negative impact on natural systems and human activities, especially related to the elasticity of water resources. The risk of vulnerability of water resources in Ambon City should be anticipated in the period from December to April and during the transition period of April and May. During this period, there would be a decrease in rainfall, so the estimated reserves of surface water and groundwater in the future will be reduced, which is accompanied by increased evapotranspiration in the dry seasons.

\subsection{Water Availability Simulation}

Based on the results of the simulation model of SWAT the description of the hydrological watersheds condition in Ambon City was marked by an increase in average surface flow and a decrease in average groundwater flow (Table 2 and 3 ) on seven watersheds that flow into the Gulf of Ambon and into the Banda Sea. The watersheds that flow into the Gulf of Ambon including Air Manis, Passo, Wae Lela, Wae Sikula, as well as several streams of Hutumury and Wae Batu Merah located in the north of Ambon City, while for the watersheds that flow in the Banda Sea is a Tulehu, as well as several streams of Hutumury and Wae Batu Merah located in the southern of Ambon City. 
Table 2. Surface flow condition on watersheds in Ambon City

\begin{tabular}{|llrrrr|} 
No & Watershed & \multicolumn{2}{c}{ Surface Flow $(\mathbf{m m})$} & Rate of Changes & $\begin{array}{r}\text { Surface Flow Prediction } \\
\text { on 2035s }(\mathbf{m m})\end{array}$ \\
\hline $\mathbf{1}$ & Air Manis & $40,201.60$ & $54,881.22$ & 733.98 & $69,560.84$ \\
\hline $\mathbf{2}$ & Hutumury & $25,479.33$ & $53,669.72$ & $1,409.52$ & $81,860.11$ \\
$\mathbf{3}$ & Passo & $28,681.52$ & $54,350.41$ & $1,283.44$ & $80,019.30$ \\
\hline $\mathbf{4}$ & Tulehu & $1,167.60$ & $1,986.33$ & 40.94 & $2,805.06$ \\
\hline $\mathbf{5}$ & Wae Batu Merah & $79,139.51$ & $124,858.67$ & $2,285.96$ & $170,577.83$ \\
\hline $\mathbf{6}$ & Wae Lela & $26,446.54$ & $50,449.33$ & $1,200.14$ & $74,452.12$ \\
\hline $\mathbf{7}$ & Wae Sikula & $37,096.29$ & $61,639.21$ & $1,227.15$ & $86,182.13$ \\
& Total & $238,212.39$ & $401,834.89$ & $8,181.12$ & $565,457.39$ \\
\hline
\end{tabular}

Table 3. Base flow (ground water) condition on watersheds in Ambon City

\begin{tabular}{|c|c|c|c|c|c|}
\hline \multirow[t]{2}{*}{ No } & \multirow{2}{*}{ Watershed } & \multicolumn{2}{|c|}{ Ground Water $(\mathrm{mm})$} & \multirow{2}{*}{$\begin{array}{l}\text { Rate of Changes } \\
(\mathrm{mm})\end{array}$} & \multirow{2}{*}{$\begin{array}{l}\text { Ground Water } \\
\text { Prediction on 2035s } \\
(\mathrm{mm})\end{array}$} \\
\hline & & Past Condition & Actual Condition & & \\
\hline 1 & Air Manis & $13,952.92$ & $9,167.30$ & -239.28 & $4,381.68$ \\
\hline 2 & Hutumury & $42,484.55$ & $29,314.56$ & -658.50 & $16,144.57$ \\
\hline 3 & Passo & $29,154.99$ & $22,153.52$ & -350.07 & $15,152.05$ \\
\hline 4 & Tulehu & $1,192.78$ & 687.35 & -25.27 & 181.92 \\
\hline 5 & Wae Batu Merah & $42,796.23$ & $43,624.92$ & 41.43 & $44,453.61$ \\
\hline 6 & Wae Lela & $36,529.00$ & $31,228.88$ & -265.01 & $25,928.7 €$ \\
\hline 7 & Wae Sikula & $18,396.50$ & $17,184.80$ & -60.59 & $15,973.1 \mathrm{C}$ \\
\hline & Total & $184,506.97$ & $153,361.33$ & $-1,557.28$ & $122,215.6 \mathrm{~s}$ \\
\hline
\end{tabular}

The increase in surface flow illustrates the flow rate fluctuations during the rainy season and the deficit flow in the dry season. The total precipitation that falls in each watershed almost entirely becomes surface runoff, thus lowering the water flow laterally and groundwater potentially supply water into river in the dry season. Hydrologic conditions such as surface flow, groundwater flow and water availability in each watershed that affect water resources in Ambon City during the period of 1987-1996 (past condition) were compared with the period of 2004-2014 (present condition). Information and phenomenon during the period of analysis, in addition to the results Spatial Plan of Ambon City should give better results on water availability. However, some of the land uses in the watershed were found not suited to its purpose. If the spatial plan in Ambon city will be implemented and simulated using SWAT models, the water availability in some of the watershed will be lower at end year of planning period. The adoption of the spatial plan will greatly affect the future of water availability and water demand in the community of Ambon City. Based on the actual conditions in 2015, the analysis of the level of water demand in the Ambon City reached $79,448,856.99 \mathrm{~m}^{3}$ the details as presented in Table 4. The total water demand in the Ambon City is shown in Table 4. The level of water availability is shown in Table 5. All seven watersheds in Ambon are continuously providing water resources. However, the calculation of water availability cannot be carried out for all watersheds, but based a watershed that supplies water for each district.

Table 4. Water demand per district in Ambon City

\begin{tabular}{|c|c|c|}
\hline No & District & Water Demand (m3) \\
\hline 1 & Baguala & $17,685,666.51$ \\
\hline 2 & Leitimur Selatan & $10,219,713.26$ \\
\hline 3 & Teluk Ambon & $34,881,443.91$ \\
\hline 4 & Nusaniwe & $7,806,268.52$ \\
\hline \multirow[t]{2}{*}{5} & Sirimau & $8,855,764.79$ \\
\hline & Total & $79,448,856.99$ \\
\hline
\end{tabular}


Tabel 5. Water yield condition on watersheds in Ambon City

\begin{tabular}{|lrrrrrr} 
No & \multicolumn{1}{c}{ Watershed } & \multicolumn{2}{c}{ Water Yield $\mathbf{( m 3 )}$} & $\begin{array}{c}\text { Rate of } \\
\text { Changes } \\
\text { (mm) }\end{array}$ & $\begin{array}{r}\text { Water Yield } \\
\text { Prediction on 2035s } \\
\text { (m3) }\end{array}$ & $\begin{array}{c}\text { Water Yield based } \\
\text { on Spatial Plan } \\
\text { (m3) }\end{array}$ \\
\hline $\mathbf{1}$ & Air Manis & $162,636,020.0$ & $129,287,000.0$ & $-1,667.45$ & $95,937,980.0$ & $143,613,290.00$ \\
\hline $\mathbf{2}$ & Hutumury & $235,634,860.0$ & $206,655,470.0$ & $-1,448.97$ & $177,676,080.0$ & $201,306,830.00$ \\
\hline $\mathbf{3}$ & Passo & $140,156,930.0$ & $138,339,820.0$ & -90.86 & $136,522,710.0$ & $131,455,880.00$ \\
\hline $\mathbf{4}$ & Tulehu & $3,907,230.0$ & $3,255,630.0$ & -32.58 & $2,604,030.0$ & $2,927,470.00$ \\
\hline $\mathbf{5}$ & Wae Batu Merah & $315,314,660.0$ & $325,133,070.0$ & 490.92 & $334,951,480.0$ & $319,546,060.00$ \\
\hline $\mathbf{6}$ & Wae Lela & $130,874,700.0$ & $132,080,880.0$ & 60.31 & $133,287,060.0$ & $127,716,520.00$ \\
\hline $\mathbf{7}$ & Wae Sikula & $138,486,950.0$ & $141,796,850.0$ & 165.50 & $145,106,750.0$ & $136,029,640.00$ \\
\hline & Total & $1,127,011,350.0$ & $1,076,548,720.0$ & & $1,026,086,090.0$ & $1,062,595,690.00$ \\
\hline
\end{tabular}

The prediction of water availability on 2035s in the Ambon City was analyzed using temporal data changes in the activity of land (land use) using the rate of change water availability for a period of 20 years (the periods 1987-1996 and 2004-2013). The prediction has resulted to the potential significant decrease of the conditions of water supply in Ambon City. This negative change will occur, if the spatial plan for the development of Ambon City having seven watersheds, in particular in the Gulf of Ambon do not pay attention to the aspects of the hydrological balance in particular by reducing the high rate of surface runoff during the rainy season (Figure 4).

Figure 4. (a) Map of water yield period 1987-1996, (b) map of water yield period 2004-2013

(c) map of water yield period 2035s (Prediction) (d) map of water yield base on spatial planning

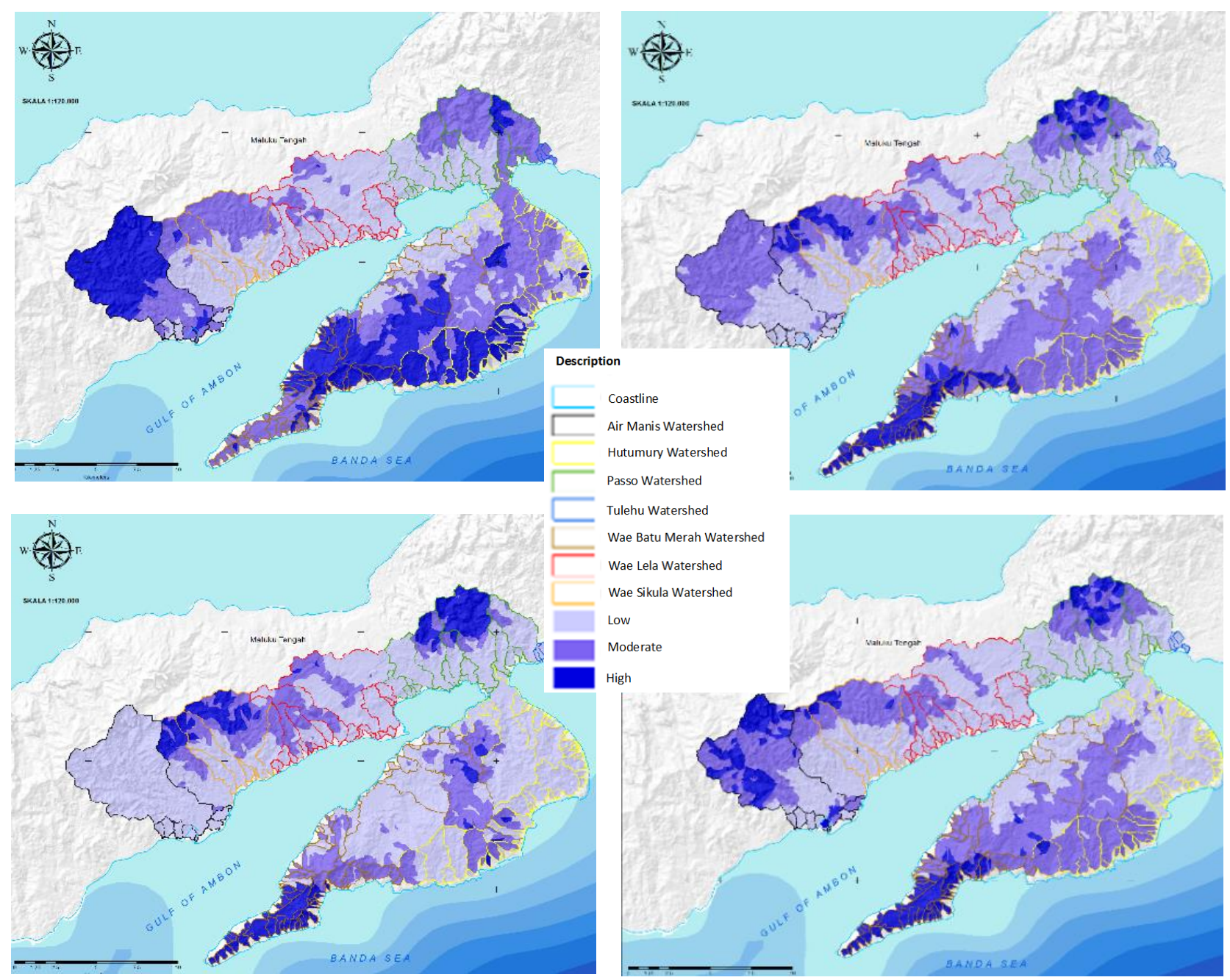


The level of reduction in water availability was not affecting all districts in Ambon City. However, one district, Baguala will have water deficit in the future. District Baguala is an urban center and trade which have an imbalance affecting the region between water needs with the availability of water supplied from the watershed. The deficit was due to only $10 \%$ of current water available in the sub-basins watershed. This deficit affected clearly the District Baguala (Figure 5).

Figure 5. Map of deficit rate of water yield in Ambon City

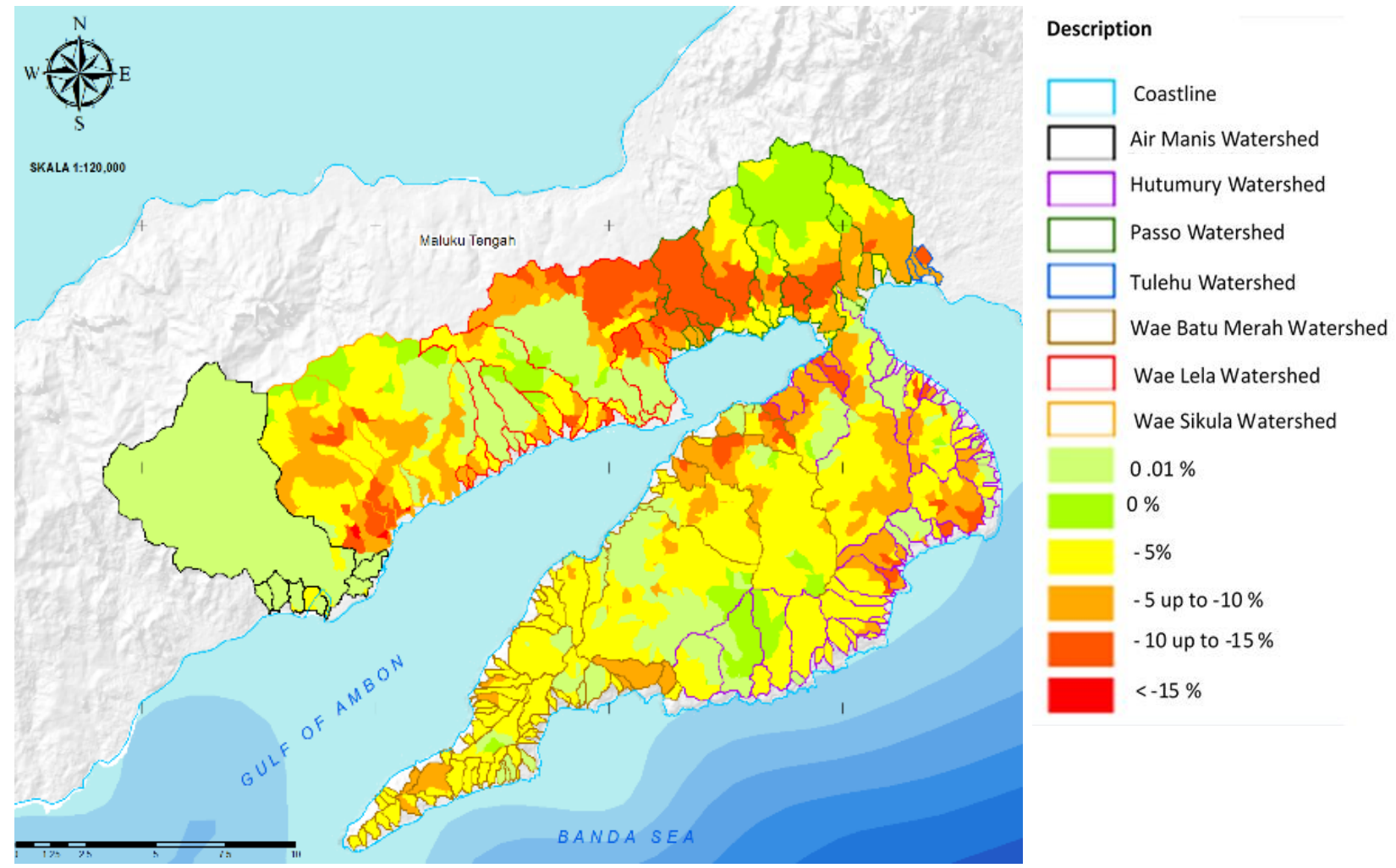

Even though water availability is on deficit level, the overall water demand is still in line with the water supply. However, if the land use changes carry on without regarding the rules of soil and water conservation, the rate of changes of water availability will create negative impacts in the future. In particular, the concerned impact can already be observed in actual period by the decreased rainfall intensity in Ambon City. This condition will aggravated the scarce of water resources in the Ambon City. Thus, spatial planning is necessary to improve the condition. Without water, all activities cannot be optimum and sustained affecting the decrease of society's welfare.

\subsection{Land Utility Plan in Ambon City}

Preventing a decrease in water availability needs to be done to achieve water security in the future. However, it should be noted that the achievement of water security will be more complex in regard to the context of population growth and rapid urbanization, the increasing demand for water, food and energy. Climate change and variability correspondingly raise additional concerns, which will be explored in more detail in the rehabilitation efforts in the Ambon City. One of the efforts that could be made is to maintain forested lands and to improve the application of spatial pattern plan for all areas. Creating infiltration wells and water harvesting in residential areas and office buildings, education, business area and regional trade will be required. Water harvesting with water storage and manufacture of wetlands/swamp artificial can be made artistic implementing agroforestry systems for appropriate designated region. Banuwa (2013) explained that vegetation that could reduce the runoff and erosion was affected by canopy height, vegetation density and density of roots. It is also stated by Asdak (1995), that vegetation has a role as a 
protective layer or buffer between the atmosphere and the soil to reduce erosion. Vegetation can affect interception of rainwater, runoff, rain destructive power and runoff on the ground. The utility plan directives for land use and spatial plan control in Ambon City are presented in Table 6.

Table 6. Utility plan directives for land use and spatial plan control in Ambon City

\begin{tabular}{|c|c|c|}
\hline No & Land-Use and Spatial Plan & Utility Plan Directives \\
\hline 1 & Forest Area & Maintained condition, in order to remain forest \\
\hline 2 & $\begin{array}{l}\text { Spatial Plan Directives for Forest Area but the } \\
\text { condition is not forest }\end{array}$ & $\begin{array}{l}\text { Modified condition, become vegetated land } \\
\text { (rehabilitation) }\end{array}$ \\
\hline 3 & Dryland Agriculture & Attempts to apply the concept of Agroforestry \\
\hline 4 & $\begin{array}{l}\text { The status of spatial plan not to forest area and } \\
\text { built up area }\end{array}$ & $\begin{array}{l}\text { Area with the basic building coefficient ( } 40 \%) \text { and open } \\
\text { green spaces }(60 \%)\end{array}$ \\
\hline 5 & $\begin{array}{l}\text { Public Zone (Commerce, Office, Education, } \\
\text { Business) }\end{array}$ & $\begin{array}{l}\text { Attempts are green open space (Minimum } 20 \% \text { ) in the } \\
\text { region and are equipped with infiltration wells or biopori }\end{array}$ \\
\hline 6 & Wetland Agriculture & $\begin{array}{l}\text { Preserved as agriculture Wetlands with implementing } \\
\text { soil and water conservation techniques }\end{array}$ \\
\hline 7 & Green belt area & Follow the rules that have been determined \\
\hline
\end{tabular}

\section{CONCLUSION}

There are seven watersheds with an area of 30,638 ha affecting Ambon City. Watershed management in the Ambon City had a relatively high degree of difficulty due to the form of watershed with generally small and elongated and steep topography. Simulation of water availability in the period 1987-1996 has calculated the value of as much as 1,127,011,350 $\mathrm{m}^{3}$ and the period 2004-2013 has generated the value of as much as $1,076,548,720 \mathrm{~m}^{3}$. The second period illustrated the decrease in water availability in Ambon due to the capacity of particular sub-basins in which the decrease of water yield as the impact of development was the source of changes in land cover. Regulation for the city development is required to ensure the water availability in the Ambon City and should be maintained in the future. Analysis of spatial pattern plan for the Ambon City indicated a deficit of water availability at end year of planning period. Therefore reconsideration for sustainability development should be extended.

\section{ACKNOWLEDGMENTS}

The author would like to thank the Center of Development Control in Eco region Sulawesi and Maluku, Ministry of Environment and Forestry, Indonesia for their support in terms of funding, data collection, and field survey for the completion of the study.

\section{REFERENCES}

Arnold, J. G., et al. (2013). Soil \& Water Assessment Tool: Input/output documentation. Version 2012. Texas Water Resources Institute, TR-439, 650. Retrieved from http://swat.tamu.edu/media/69296/SWATIO-Documentation-2012.pdf

Asdak, C. (1995). Hydrology and watershed management. Yogyakarta: Gadjah Mada University Press.

Banuwa, I. S. (2013). Erosi. Kencana Prenada Media Group. Jakarta.

BSN. (2015). SNI 6728.1:2015-Penyusunan neraca spasial sumber daya alam. Jakarta. Retrieved from http://sisni.bsn.go.id/index.php/sni_main/sni/detail_sni/22945

Butt, A., et al. (2015). Land use change mapping and analysis using Remote Sensing and GIS: A case study of Simly watershed, Islamabad, Pakistan. The Egyptian Journal of Remote Sensing and Space Science, 18(2), 251-259. [CrossRef]

Chen, Y.-R., \& Yu, B. (2015). Impact assessment of climatic and land-use changes on flood runoff in southeast Queensland. Hydrological Sciences Journal, 60(10), 1759-1769. [CrossRef]

CSIRO. (2012). The impacts of climate change and urban development on future water security and adaptation options for Makassar City, Indonesia. 
Iqbal, M., et al. (2012). Anthropogenic impact on Landuse/Landcover in Dudhganga Watershed of Kashmir Valley, India. International Journal of Geomatics and Geosciences, 2(3), 902.

Jacob, A. (2009). Alternatif pengelolaan lahan optimal untuk pelestarian sumber daya air di pulau Ambon. Bogor Agricultural University. http://repository.ipb.ac.id/handle/123456789/40577

Khoi, D. N., \& Suetsugi, T. (2014). The responses of hydrological processes and sediment yield to land-use and climate change in the Be River Catchment, Vietnam. Hydrological Processes, 28(3), 640-652. [CrossRef]

Lokollo, J. A. (2000). Analysis of Effect Spatial Plan Changes to the Water Balance: A Case Study of Ambon City, Maluku. Bogor Agricultural University.

Memarian, H., Tajbakhsh, M., \& Balasundram, S. K. (2013). Application of SWAT for impact assessment of land use/cover change and best management practices: a review. International Journal of Advancement in Earth and Environmental Sciences, 1(1), [CrossRef]

Niraula, R., Meixner, T., \& Norman, L. M. (2015). Determining the importance of model calibration for forecasting absolute/relative changes in streamflow from LULC and climate changes. Journal of Hydrology, 522, 439-451. [CrossRef]

Olivera, F., et al. (2006). Arcgis-SWAT: A Geodata Model and GIS Interface For SWAT. Journal of the American Water Resources Association, 42(2), 295-309. [CrossRef]

Pervez, M. S., \& Henebry, G. M. (2015). Assessing the impacts of climate and land use and land cover change on the freshwater availability in the Brahmaputra River basin. Journal of Hydrology: Regional Studies, 3, 285-311. [CrossRef]

Putuhena, J. D. (2013). Watershed Management Dinamic Model in Sustainable Water Supply Efforts in Ambon Island Peninsula Leitimor. Bogor Agricultural University.

Sarwuan, T., Beka, F. T., \& Ogbole, A. (2016). Geographic Resource Monitoring and Assessment of LongTerm Land Cover Change. Journal of Scientific and Engineering Research, 3(3), 646-655.

Schilling, K. E., et al. (2014). The potential for agricultural land use change to reduce flood risk in a large watershed. Hydrological Processes, 28(8), 3314-3325. [CrossRef]

Zhang, Y., et al. (2016). Impact of Land Use on Frequency of Floods in Yongding River Basin, China. Water, 8(9), 401. [CrossRef] 